\title{
Civil Liability for Negligent Police Investigation: Canadian Developments
}

\author{
Marc W. Patry* \\ Saint Mary's University, Halifax, Nova Scotia, Canada
}

\begin{abstract}
In October of 2007, the Supreme Court of Canada issued its ruling in Hill v. Hamilton-Wentworth Regional Police Services Board, a case in which the Court addressed the legitimacy of a tort for negligent police investigation. The holding by a majority of six Justices recognized the tort of negligent police investigation at Canadian law. As such, Canada is now one of the only common law countries to have recognized such a tort. This paper summarizes the case and addresses its implications for the Canadian law enforcement community.
\end{abstract}

Keywords: Civil liability, policing, investigation.

\section{CIVIL LIABILITY FOR NEGLIGENT POLICE IN- VESTIGATION: CANADIAN DEVELOPMENTS}

This paper summarizes the recent Hill ruling and discusses its implications for Canadian police. First is a summary of the case facts, followed by a summary of the lower court and Supreme Court of Canada decisions, and then a discussion of implications including some recommendations for Canadian law enforcement agencies.

\section{SUMMARY OF CASE FACTS}

In 1996, Jason Hill was wrongfully convicted of a robbery charge. He was eventually acquitted after a new trial was ordered on the basis of a successful appeal. Hill spent a total of more than 20 months incarcerated. Hill later filed suit against the Hamilton-Wentworth Regional Police Services Board, the individual police officers involved in his case, and the Crown Attorneys involved in his investigation and prosecution. Hill ceased action against the Crown and some of the individual officers before the matter reached trial.

Originally, the police suspected Hill of committing 10 robberies that had occurred in 1994 and 1995 in Hamilton, Ontario. Police began to suspect Hill after they received a tip, and subsequently a police officer identified Hill from a surveillance photograph from one of the robberies. There was a potential sighting by an officer of Hill near the scene of one of the robberies. Additionally, some witnesses identified the robber as being aboriginal, which matches Hill's ethnicity. Police circulated Hill's photo in the popular media while the investigation was ongoing. Photo lineups with witnesses were constructed with Hill's photo and 11 Caucasian foils who were similar in appearance to Hill.

During the investigation, police acquired information that two Hispanic men, one of whom looked like Hill, were in fact the robbers. After Hill was incarcerated, two additional similar robberies took place. Hill was charged with 10 counts of robbery, but police dropped all but one of those charges

*Address correspondence to this author at the Saint Mary's University, Halifax, Nova Scotia, Canada; E-mail: Marc.Patry@smu.ca before the Crown Attorney moved forward. Testimony from two witnesses from that robbery resulted in a conviction on that charge. On appeal, Hill was allowed a new trial. He was acquitted in the second trial. Hill then brought suit against the police on the basis of an allegation of negligent investigation.

\section{SUMMARY OF THE LOWER COURT PROCEED- INGS}

Hill's negligence claim was based on several specific aspects of the investigation. For one, he claimed the police were negligent in their conduct regarding two bank tellers who identified him. Specifically, Hill alleged police negligence with regard to the identification proceedings for the following reasons: 1) the witnesses were interviewed together, not separately as suggested in non-binding guidelines for police procedures regarding eyewitness identifications, 2) during the interview there was a newspaper photograph of Hill (which had been released to the media by police) on the witnesses' desk during the interview, and 3) Hill alleged bias in the construction of the photo lineup used to identify him. In addition, Hill claimed the police were negligent because they did not cease to consider him a suspect when new evidence surfaced that potentially exculpated him.

In the original civil trial, Hill's negligence claim was dismissed. The Ontario Superior Court judge presiding over the original civil trial recognized the tort of negligent investigation, but dismissed the charges based on a conclusion that the conduct of the police officers during Hill's investigation, while imperfect, was not negligent because it did not differ from the conduct of a reasonable officer in similar circumstances.

Hill appealed the decision. The Court of Appeal unanimously recognized the tort of negligent investigation, but a majority of three justices held that the police had not been negligent in Hill's case. Two dissenting justices found that the police had been negligent in their failure to reinvestigate on the basis of potentially exculpatory evidence, and that the trial judge had erred in allowing the lineup which, in their view, was biased based on the fact that it consisted of 11 Caucasian foils and one aboriginal suspect, Hill. 


\section{SUMMARY OF SUPREME COURT OF CANADA DECISION}

The Supreme Court of Canada agreed to hear the case on the basis of Hill's appeal regarding the finding that the police were not negligent in his case. In addition, the police filed a cross-appeal which contended that the tort of negligent investigation does not exist in Canadian law. This was the first time the Supreme Court of Canada had addressed the question of whether there is a tort for negligent investigation by the police. The Court dismissed both the appeal and the cross-appeal. The majority recognized the tort of negligent investigation, but held that the police were not negligent in Hill's case.

In a general sense, successful claims of negligence require four elements at Canadian civil law: 1) that a duty of care existed between the plaintiff and the defendant, 2) that the standard for that duty of care was not met by the defendant, 3) that the plaintiff suffered compensable losses, and 4) that the defendant's negligent actions caused the plaintiff's loss. In this case, the Court addressed for the very first time the question of whether there is a duty of care between police and the individual criminal suspects in their investigations.

The Court's decision recognizes that the police have a duty of care to criminal suspects; the duty of care is held to a standard of the reasonable officer. The majority opinion elaborated justification for the tort of negligent investigation, and weighed the policy considerations that might result from recognition of the tort. Below is a summary of the majority's reasoning with regard to the existence of a duty of care between police and criminal suspects. In addition, there is a summary of their analysis of the potential policy implications of recognizing the tort of negligent investigation, and the conclusion that there is not sufficient evidence for detrimental policy implications to negate that duty of care.

\section{The Majority Opinion}

The majority opinion, written by Chief Justice McLachlin and joined by Justices Binnie, LeBel, Deschamps, Fish, and Abella, elaborated the law of negligence as it applies to the question of the relationship between the police and criminal suspects. The opinion establishes that a duty of care exists if a relationship between two people has the proximity and foreseeablity to establish a prima facie duty of care. Therefore, the legal analysis of the question of a duty of care relies on two determinations: whether there is foreseeability that negligence will result in harm, and whether the relationship is of close enough proximity to impose a legal liability on the accused wrongdoer. In addition, in establishing a duty of care, there must be a consideration of the greater policy impact of recognizing that duty of care, which may negate or limit it. The leading case on determination of the existence of a duty of care is Anns v. Merton London Borough Council (1978), in which the Court established a two-stage test (i.e., the Anns test) for determination of a duty of care: 1) establishing a prima facie duty of care (based on foreseeability and proximity), and 2) analysis of the policy considerations potentially limiting or negating such a duty of care.

The question of foreseeability is answered in the affirmative without much substantive analysis: it is clear that police officers can foresee the potential harm to suspects inherent in their investigation. Proximity analysis depends on the circumstances of the case and varies substantially from one context to the next. The basic question is whether a relationship is close and direct enough to impose a legal duty of care (assuming foreseeability), and the majority opinion clearly states that there is no rule barring consideration of the proximity of new, not-as-yet recognized types of relationships for proximity: "The result is a concept of liability for negligence which provides a large measure of certainty, through settled categories of liability-attracting relationships, while permitting expansion to meet new circumstances and evolving conceptions of justice." (p. 27). In their proximity analysis, the majority clearly distinguishes their analysis as pertaining only to the police-suspect relationship, and not to other types of relationships between the police and community members, such as the relationship between the police and crime victims. The majority found a close, personal, direct relationship between the police and a specific suspect that they have identified in their investigation, in this case Mr. Hill. In addition, the majority considered the high stakes to the individual suspect as a facet of the proximity analysis, "The targeted suspect has a critical personal interest in the conduct of the investigation. At stake are his freedom, his reputation and how he may spend a good portion of his life. These high interests support a finding of a proximate relationship giving rise to a duty of care." (p. 32). Thus, the majority concluded that the police have a prima facie duty of care to particularized suspects in their investigations, satisfying the first stage of the Anns test for establishing a legal duty of care.

The majority distinguished the issue of liability for negligent investigation from other, already-established civil remedies against police, namely false imprisonment, false arrest, and malicious prosecution. The majority noted the importance of legal recourse for non-malicious, negligent police investigation: "To deny a remedy in tort is, quite literally, to deny justice. This supports recognition of the tort of negligent police investigation, in order to complete the arsenal of already existing common law and statutory remedies." (p. 32). As part of their reasoning, the majority noted clear evidence of non-malicious police negligence in a number of past investigations of wrongful convictions, including the Thomas Sophonow inquiry and the Lamer Commission inquiry (Cory, 2001; Federal/Provincial/Territorial Heads of Prosecutions Committee Working Group, 2004; Kaufman, 1998; Lamer, 2006).

In regards to the second stage of the Anns test, whether significant policy implications limit or negate a duty of care, the majority engaged in a detailed analysis of a number of specific arguments, each of which were ultimately dismissed: "In this case, negating conditions have not been established. No compelling reason has been advanced for negating a duty of care owed by police to particularized suspects being investigated. On the contrary, policy considerations support the recognition of a duty of care.” (p. 37-38).

One argument against establishing a duty of care to individual suspects is that it would be in conflict with the police duty to protect the public by preventing crime. The majority dismissed that argument, "The officer's duty to the public is not to investigate in an unconstrained manner. It is a duty to investigate in accordance with the law... The duty of investigation in accordance with the law does not conflict with the 
presumed duty to take reasonable care toward the suspect." (p. 35).

The majority considered, and dismissed, a number of policy-based arguments against recognition of the tort of negligent investigation that were advanced by the respondents and interveners. Those arguments included the following: that recognizing the duty of care would cause police work to become 'quasi-judicial' in nature, that some normal police duties would be in conflict with a duty of care to criminal suspects, that recognition of a duty of care would negatively impact the discretion inherent to police work, that recognition of a tort of negligent investigation would have a chilling effect on the investigation of crime, and that a flood of litigation will result from recognition of the tort of negligent investigation.

The argument that police work would become quasijudicial in nature advanced the notion that decisions made by police with regard to their investigations would basically be similar to prosecutorial decisions. Essentially, the argument was that recognizing a duty of care to criminal suspects would require police to make determinations of the legal guilt or innocence of a suspect before proceeding with their investigation. The majority opinion, however, noted that the police role is to collect evidence in the investigation to the standard of a reasonable officer. As long as police act reasonably, then they would be protected from liability regardless of whether the evidence that they collected was sufficient to result in a conviction at law, or whether the Crown or the courts used the information in an unreasonable way:

Where the police investigate a suspect reasonably, but lawyers, judges or prosecutors act unreasonably in the course of determining his legal guilt or innocence, then the police officer will have met the standard of care and cannot be held liable either for failing to perform the job of a lawyer, judge or prosecutor, or for the unreasonable conduct of other actors in the criminal justice system. (p. $39)$.

The majority did not agree that recognition of a duty of care to criminal suspects would result in confusion with regard to the standard of care afforded to suspects at the time of arrest; it had been argued that recognizing a tort of negligent investigation would raise the standards for arrest.

The majority dismissed the argument that, because discretion is an essential aspect of law enforcement, that fact should negate a duty of care to criminal suspects. The majority illustrated similarities between professional standards for police with regard to discretion and the standards for discretion of other types of professionals, such as law and medicine, for which a tort of negligence has been established. "Professionals in these fields are subject to a duty of care in tort nonetheless, and the courts routinely review their actions in negligence actions without apparent difficulty." (p. 40). The majority went on to elaborate the point that recognition of a tort of negligence does not limit discretion, and that professionals are allowed to exercise discretion so long as they do not act unreasonably.

The majority made a detailed discussion of the argument that the tort of negligent investigation would have a chilling effect on the investigation of crime. This argument basically asserted that, as a result of civil liability for negligent investigation, police would be deterred from investigating suspects except when the evidence was so compelling as to almost guarantee a conviction. The majority acknowledged the possibility that the duty of care might cause police to be more careful in their investigations, but they concluded that would be a good thing. In the context of reviewing the available evidence regarding the possible dampening effect that the tort of negligence might have on police behaviour, the majority concluded:

The record does not support the conclusion that recognizing potential liability in tort significantly changes the behaviour of police. Indeed, some of the evidence suggests that tort liability has no adverse effect on the capacity of police to investigate crime. This supports the conclusion of the majority in the Court of Appeal below that the “"chilling effect' scenario" remains speculative and that concern about preventing a "chilling effect" on the investigation of crime is not (on the basis of present knowledge) a convincing policy rationale for negating a duty of care...the studies adduced in this case do not support the proposition that recognition of tort liability for negligent police investigation will impair it...it should also be noted that many police officers (like other professionals) are indemnified from personal civil liability in the course of exercising their professional duties, reducing the prospect that fear of civil liability will chill crime prevention (pp. 42-44).

Essentially, the majority concluded that speculation about a chilling effect on the investigation of crime, absent evidentiary support, was insufficient justification for negating a duty of care at the policy-consideration stage of the Anns test.

The majority also debated the possibility that recognition of a duty of care between police and criminal suspects would cause a flood of litigation against the police. Here again, the majority concluded that the evidence supporting such a claim was not apparent, and that speculation about that possibility was insufficient to trigger a policy-based negation of the tort of negligent investigation. The majority reiterated the conclusion reached by the Court of Appeal, and noted that evidence from two jurisdictions in Canada which have longrecognized the tort of negligent investigation does not support the notion that such a tort will give rise to a costly flood of litigation:

The record provides no basis for concluding that there will be a flood of litigation against the police if a duty of care is recognized. As the Court of Appeal emphasized, the evidence from the Canadian experience seems to be to the contrary...Quebec and Ontario have both recognized police liability in negligence (or the civil law equivalent) for many years, and there is no evidence that the floodgates have opened and a large number of lawsuits against the police have resulted...The best that can be said from the record is that recognizing a duty of care owed by police officers to particular suspects led to a relatively small number of lawsuits, the cost of which are unknown, with effects on the police that have not been measured. This is not enough to negate the prima facie duty of care established at the first stage of the Anns test. (pp. 44-45). 
The majority also discussed a concern raised by the dissent, namely that guilty persons who are acquitted may then sue the police, which would be unjust. The majority dismissed that argument on the basis that all torts have similar risks; anyone who seeks redress through the civil justice system may, in fact, be lying.

In applying the tort of negligent investigation to the facts in Hill's case, the majority concluded that the trial judge had not erred in concluding an absence of negligence. "While the investigation that led to Mr. Hill's arrest and conviction was flawed, I conclude that it did not breach this standard, judged by the standards of the day." (p. 51). The majority addressed each of Hill's specific allegations of police negligence, four of which pertained to the pre-arrest stage of his investigation: 1) witnesses evidence was contaminated when police released his photograph to the media, 2) the police did not make accurate records of their interviews with witnesses against Hill, 3) it was negligent for police to interview two witnesses simultaneously and when there was a photograph of Hill on the desk in front of them, 4) the photo lineup used to identify Hill was structurally biased. The majority noted problems with each of these pre-arrest allegations based on contemporary standards of police conduct, but concluded that none of the irregularities breached the standard of care of a reasonable officer in similar circumstances.

The first four complaints, while questionable, were not sufficiently serious on the record viewed as a whole to constitute a departure from the standard of a reasonable police officer in the circumstances. The publication of Hill's photo, the somewhat incomplete record of witness interviews, the fact that two witnesses were interviewed together and the failure to blind-test the photos put to witnesses are not good police practices, judged by today's standards. But the evidence does not establish that a reasonable officer in 1995 would not have followed similar practices in similar circumstances...It cannot be concluded that the photo lineup was unreasonable, judged by 1995 standards...A reasonable officer today might be expected to avoid lineups using foils of a different race than the suspect, to avoid both the perception of injustice and the real possibility of unfairness to suspects who are members of minority groups. (p. 53-54).

The Court also considered an allegation of negligence in that the police failed to fully investigate new evidence suggesting that Hill was not the culprit. There were a number of telephone tips suggesting that two other individuals were responsible for the robberies. Hill argued that this fact should have had more weight in the police investigation, especially when combined with a number of weaknesses in the case against Hill. The police failed to find any incriminating evidence in a search of Hill's home, and the perpetrator had been described by eyewitnesses as clean-shaven and Hill had several weeks' growth of facial hair when he was arrested. Also, the robberies continued after Hill was in custody. The majority concluded, however, that the failure to reinvestigate Hill's case in light of the new evidence did not rise to the level of negligence:

When new information emerges that could be relevant to the suspect's innocence, reasonable police conduct may require the file to be reopened and the matter reinvestigated...At the same time, police investigations are not never-ending processes extending indefinitely past the point of arrest. Police officers acting reasonably may at some point close their case against a suspect and move on to other matters. The question is always what the reasonable officer in like circumstances would have done to fulfil the duty to reinvestigate and to respond to the new evidence that emerged. (p. 57).

\section{The Minority Opinion}

The minority opinion was written by Justice Charron and joined by Justices Bastarache and Rothstein. The minority disagreed with the majority's conclusion that the tort of negligent investigation exists in Canadian law, asserting that the greater policy implications of recognizing a duty of care to criminal suspects negate recognition of the tort. "The overly cautious approach that may result from the imposition of conflicting duties would seriously undermine society's interest in having the police investigate crime and apprehend offenders." (p. 88, emphasis in original). The minority cited prior decisions by the Supreme Court of Canada in which the Court refused to impose a duty of care on professionals because fear of litigation might hamper those professionals' more general duties with respect to the public at large. In Cooper v. Hobart (2001), the Court found no duty of care for mortgage brokers and their clients because of concern such a duty would conflict with their general duty to the public, and in Edwards v. Law Society of Upper Canada (2001), the Court declined to impose a duty of care on the Law Society of Upper Canada with regard to neglecting to protect potential fraud victims from a solicitor; the Court ruled that such a duty of care would create fear of litigation which would interfere with the Law Society's investigatory capacity and its duty to the general public.

According to the Hill minority, "The interests of the public in having police officers investigate crime and the interests of suspects are inherently and diametrically opposed." (p. 91). The minority viewed the imposition of a duty of care as likely to have a major impact on the use of police discretion:

If this Court accepts Mr. Hill's argument, the investigating officer will be legally bound, not only to fulfill his or her public duty to enforce the law, but also to take care not to harm the suspect by conduct that may ultimately be found to fall below the relevant standard of care... Of course, the surest way of avoiding harm to the suspect is for the officer to decide to not issue process and not engage the criminal law...the police officer may well choose to avoid any risk of harm to the suspect by the exercise of "police discretion". Since there is a significant gap between the "reasonable and probable grounds" standard to issue process and the "beyond a reasonable doubt" standard to convict, the prudent officer who tries to reconcile his public duty to enforce the law and his private duty not to harm the innocent suspect may be well advised not to issue process except in cases where the evidence is overwhelming. (pp. 94-95).

The minority discussed at some length their reasons for believing that recognition of a tort of negligent investigation was an error of law which would lead to substantial negative outcomes. One area of emphasis in the minority opinion per- 
tained to what they viewed as problems with elements of loss and causality in this tort. According to the minority, the distinction between findings of 'not guilty' and 'guilty' in criminal contexts would lead to substantive problems arriving at conclusions of loss and causality. Because a finding of 'not guilty' does not equate to a finding of 'factually innocent', the minority view was that the de facto default determination at law would require treating a not guilty verdict as a determination of factual innocence, which would lead to the problem of persons who are actually guilty, but who were found to be not guilty in criminal proceedings, seeking redress for losses ostensibly obtained as a result of their 'wrongful' prosecution.

The minority view, of course, did not prevail in the Hill case. The summary of the minority view in this case may, however, be of interest to police and legal professionals who may wish to see the Court revisit the issue of negligent investigation in the future. While this was a 6-3 decision, changes in the composition of the Court could sway the balance of views away from recognition of this tort.

\section{IMPLICATIONS FOR LAW ENFORCEMENT}

What are the implications of Hill in terms of Canadian policing? Most obviously, police in Canada are now bound by a duty of care to criminal suspects; the standard is that of a reasonable officer in similar circumstances. Canada is now one of the only common law countries to have recognized such a tort. Now that the Supreme Court of Canada has recognized the tort of negligent investigation, suspects may try to sue the police if they allege negligence during the investigation.

Time will tell whether the Hill decision will have a major impact on policing in Canada. It is possible that the decision would be overturned at some point in the future, a change which is more likely if it turns out that the policy implications of this new tort are negative. However, for the time being, civil liability for police in the course of normal investigations is the law of the land. As such, there are a number of implications that Canadian police entities should consider, some of which may have practical, short-term action associated with them.

Recognition of a duty of care to criminal suspects has clear training implications for new recruits. Officers-intraining will need to be made aware of their legal duty of care to criminal suspects. Training protocols and procedural regulations should include detailed information about this duty of care and the reasonable officer standard. The better police understand this responsibility, the more likely it will be that they can perform their duties in a manner that will protect them from liability for negligent investigation. In a practical sense, it seems unlikely that this decision should trigger much in the way of substantive changes to the ways in which Canadian police train their recruits; most police activity will be consistent with the reasonable officer standard, i.e., police do not train their new officers to be negligent. However, it would behoove new recruits to be educated about their duty of care to criminal suspects and the possibility that they could be sued. In addition, it makes sense for police agencies to make existing officers aware of this responsibility, possibly most efficiently through normal inservice training and education mechanisms.
Another important consideration for Canadian police organizations is the issue of legal protection. For those agencies where individual officers do not have some form of protection from individual responsibility, the Hill decision warrants careful review of the situation and it is recommended that all Canadian police have some form of protection from individual civil liability. Individual officers should make themselves aware of their organization's legal protections for civil liability, and perhaps consider additional prophylactic measures if they are available (e.g., additional personal liability insurance). Given the possibility of increased litigation against police in the post-Hill era, Canadian police forces should look carefully at their defenses against civil liability and consider carefully their contingency plans for civil litigation.

One possible implication of the Hill decision could be diminished interest in law enforcement as a career choice, and so Canadian police forces should consider that this question could arise with new recruits as well as with officers who are already on the job. Agencies which offer indemnity protection for individual officers may have a marked recruiting advantage over agencies which do not offer protection against civil liability for individual officers. Canadian police organizations should consider carefully their position with regard to civil lawsuits against individual officers, and make known to current and potential employees what mechanisms are in place for their protection. Officers will likely want to know if the department 'has their back' in the event of a negligent investigation lawsuit. In addition, there is the possibility that Hill will cause an increased fear of litigation among police officers and administrators (see, e.g., Hall et al., 2003; Vaughn, Cooper, \& Carmen, 2001).

There will remain for some time some very important questions about whether Hill will have a major impact on Canadian law enforcement. Will there be a 'chilling effect' on police investigation of crime, such that police choose to investigate a more narrow class of suspects, those against whom the evidence is more compelling than would have been in the past? Will the tort of negligent investigation result in a flood of litigation against Canadian police? Of course, the majority opinion was based on the expectation that these outcomes are unlikely, or at least not supported by existing research based on jurisdictions that currently allow the tort of negligent investigation. However, the true impact of the Hill decision on policing in Canada remains to be seen. These are empirical questions and Canadian police agencies would do well to engage the assistance of social scientists to study the impact of Hill on Canadian policing.

What is the likelihood that the tort of negligent investigation will exist into the future? As of the Hill decision in October of 2007, the police have a duty of care to criminal suspects. It seems unlikely that the Court will reverse its decision any time in the very near future as the same issue will rarely be heard by the Court in near succession. It is likely that civil liability for negligent investigation will continue to be the law of the land in Canada indefinitely. However, there is always a possibility that the Court will reconsider the issue at some point in the future. This seems especially more likely if it becomes clear that Hill has diminished the investigatory activity of police, or resulted in other negative consequences. If there are well-documented negative effects of 
recognition of the tort of negligent investigation, then it stands to reason that the Court would consider rescinding the duty of care at some point in the future. Given that the majority's reasoning regarding the possible negative policy implications of recognizing a duty of care to criminal suspects was based heavily on an absence of evidence to that effect, it seems clear that the Court would be unlikely to change its ruling absent empirical evidence of the negative effects.

Police should consider carefully planned research to study the impact of Hill. It is not enough to imagine a study at some later time. Absent rigorous, planful methodologies in place in the near term, it is unlikely that any definitive conclusions about Hill's impact will be evident in the future. Prior research illustrates very clearly the difficult nature of research on civil litigation against police (see Archbold \& Maguire, 2002; Hughes, 2001; Vaughn, Cooper, \& del Carmen, 2001; Worrall, 1998). Assuming that authoritative conclusions can be retroactively determined from archival records is likely to be a major mistake. Research plans should be developed and implemented in the short term.

In conclusion, the Hill ruling is an important case for Canadian police to be aware of. Knowledge of the duty of care to criminal suspects is important for new recruits, as well as existing officers. Liability indemnity for individual officers should be reviewed by Canadian police agencies, and they should be prepared for the possibility of increased litigation against police in the wake of Hill.

\section{REFERENCES}

Anns, V. (1978). Merton London Borough Council House of Lords, Law Reports, Appeal Cases (Third Series) 728.

Archbold, C. A., \& Maguire, E. R. (2002). Studying civil suits against the police: A serendipitous finding of sample selection bias. Police Quarterly 5, 222-249.

Cooper, V. Hobart. (2001). 3 Canada Supreme Court Reports 537.

Cory, P. (2001). The Hobart Inquiry Regarding Thomas Sophonow: The Investigation, Prosecution and Consideration of Entitlement to Compensation. Winnipeg: Manitoba Justice.

Edwards, V. (2001). Law Society of Upper Canada. 3 Canada Supreme Court Reports 562.

Federal/Provincial/Territorial Heads of Prosecutions Committee Working Group (2004). Report on the Prevention of Miscarriages of Justice. Ottawa: Department Justice.

Hall, D. E., Ventura, L. A., Lee, Y. H., \& Lambert, E. (2002). Suing cops and corrections officers: Officer attitudes and experiences about civil liability. Policing: An International Journal of Police Strategies and Management 26, 539-547.

Hill, V. Hamilton-Wentworth Regional Police Services Board (2007). Supreme Court of Canada 41.

Huges, T. (2001). Police officers and civil liability: "The ties that bind"? Policing: An International Journal of Police Strategies and Management, 24, 240-262.

Kaufman, F. (1998). The Commission on Proceedings Involving Guy Paul Morin: Report. Toronto: Ontario Ministry of the Attorney General.

Lamer, A. (2006). The Lamer Commission of Inquiry into the Proceedings Pertaining to: Ronald Dalton, Gregory Parsons and Randy Druken: Report and Annexes. St. John's: Government of Newfoundland and Labrador.

Vaughn, M. S., Cooper, T. W., \& Del Carmen, R. V. (2001). Assessing legal liabilities in law enforcement: Police chiefs' views. Crime \& Delinquency 47, 3-27.

Worrall, J.L. (1998). Administrative determinants of civil liability lawsuits against municipal police departments: An exploratory analysis Crime \& Delinquency 44, 295-313.

(C) Marc W. Patry; Licensee Bentham Open.

This is an open access article licensed under the terms of the Creative Commons Attribution Non-Commercial License (http://creativecommons.org/licenses/by-nc/3.0/) which permits unrestricted, non-commercial use, distribution and reproduction in any medium, provided the work is properly cited. 